\title{
GURU SEBAGAI PEDOMAN DALAM PENDIDIK
}

\author{
Hanafi \\ Email: hanafi.naf99@gmail.com \\ Program Studi Pendidikan Sejarah Fakultas Keguruan dan Ilmu Pendidikan \\ Universitas Lambung Mangkurat \\ Banjarmasin
}

\begin{abstract}
Abstrak
Secara logik, setiap usaha pengembangan profesi (professionalization) harus bertolak dari konstruk profesi, untuk kemudian bergerak ke arah substansi spesifik bidangnya. Diletakkan dalam konteks pengembangan profesionalisme keguruan, maka setiap pembahasan konstruk profesi harus diikuti dengan penemukenalan muatan spesifik bidang keguruan. Lebih khusus lagi, penemukenalan muatan didasarkan pada khalayak sasaran profesi tersebut. Karena itu, pengembangan profesionalisme guru sekolah dasar atau madrasah ibtidaiyah akan menyentuh persoalan: sosok profesional secara umum, sosok profesional guru secara umum, dan sosok profesional guru sekolah dasar atau madrasah ibtidaiyah.

Profesional adalah pekerjaan atau kegiatan yang dilakukan oleh seseorang dan menjadi sumber penghasilan kehidupan yang memerlukan keahlian, kemahiran, atau kecakapan yang memenuhi standar mutu atau norma tertentu serta memerlukan pendidikan profesi.
\end{abstract}

\section{PENDAHULUAN}

profesi secara etimologi berasal dari kata profession (inggris) yang berasal dari bahasa latin profesus yang berarti ' 'mampu atau ahli dalam suatu bentuk pekerjaan '. Profesi dapat diartikan sebagai suatu pekerjaan atau jabatan yang menuntut keahlian, yang didapat melalui pendidikan dan latihan tertentu, menurut persyaratan khusus memiliki tanggung jawab dan kode etik tertentu. Profesi adalah suatu pekerjaan atau jabatan yang menuntut keahlian tertentu. artinya suatu pekerjaan atau jabatan yang di sebut profesi tidak dapat dipegang oleh sembarangan orang, tetapi memerlukan persiapan melalui pendidikan dan pelatihan secara khusus (Musriadi, 2016: 27-30).

Guru merupakan suatu profesi, yang berarti suatu jabatan yang memerlukan keahlian khusus sebagai guru dan tidak dapat dilakukan oleh sembarang orang diuar bidang pendidikan. Walaupun pada kenyataannya masih terdapat guru yang tidak memiliki latar belakang pendidikan bidang keguruan. Guru dapat melakukan melaksanakan evaluasi yang efektif serta menggunakan hasilnya untuk mengetahui peserta dan kemajuan siswa serta dapat melakukan perbaikan dan pengembangan.(Susanto,2020: 17). 


\section{PERAN GURU SEBAGAI SEBUAH PROFESI}

guru seorang menawarkan jasa dan sudah menempuh pendidikan maupun pelatihan khusus untuk menjadi seorang guru dan memiliki syarat umum sebagai pekerjaan yang di anggap profesi seperti memiliki spesialis ilmu, memiliki kode etik dalam menjalankan profesi, memiliki organisasi profesi, diakui masyarakat, sebagai panggilan hidup, dilengkapi kecakapan diagnostik, dan mempunyai klien yang jelas.

Dalam undang-undang No. 14 tahun 2005, dikatakan guru adalah pendidik profesional dengan tugas utama pendidik, mengajar, membimbing, mengarahkan, melatih, menilai, dan mengevaluasi peserta didik dengan pada pendidik anak usia dini jalur pendidikan formal, pendidikan dasar, dan pendidikan menengah.(Susanto, 2020:16)

Dalam melaksanakan tugas keprofesionalan, guru berhak:

Memperoleh penghasilan di atas kebutuhan hidup minimum dan jaminan kesejahteraan sosial;

Mendapatkan promosi dan penghargaan sesuai dengan tugas dan prestasi kerja;

Memperoleh perlindungan dalam melaksanakan tugas dan hak atas kekayaan intelektual;

Memperoleh kesempatan untuk meningkatkan kompetensi;

Memperoleh dan memanfaatkan sarana dan prasarana pembelajaran untuk menunjang kelancaran tugas keprofesionalan;

Memiliki kebebasan dalam memberikan penilaian dan ikut menentukan kelulusan, penghargaan, dan/ atau sanksi kepada peserta didik sesuai dengan kaidah pendidikan, kode etik guru, dan peraturan perundang-undangan;

Memperoleh rasa aman dan jaminan keselamatan dalam melaksanakan tugas;

Memiliki kebebasan untuk berserikat dalam organisasi profesi;

Memiliki kesempatan untuk berperan dalam penentuan kebijakan pendidikan;

Memperoleh kesempatan untuk mengembangkan dan meningkatkan kualifikasi akademik dan kompetensi; dan/atau

Memperoleh pelatihan dan pengembangan profesi dalam bidangnya.

Dalam melaksanakan tugas keprofesionalan, guru berkewajiban: 
merencanakan pembelajaran, melaksanakan proses pembelajaran yang bermutu, serta menilai dan mengevaluasi hasil pembelajaran;

meningkatkan dan mengembangkan kualifikasi akademik dan kompetensi secara berkelanjutan sejalan dengan perkembangan ilmu pengetahuan, teknologi, dan seni;

bertindak objektif dan tidak diskriminatif atas dasar pertimbangan jenis kelamin, agama, suku, ras, dan kondisi fisik tertentu, atau latar belakang keluarga, dan status sosial ekonomi peserta didik dalam pembelajaran;

menjunjung tinggi peraturan perundang-undangan, hukum, dan kode etik guru, serta nilainilai agama dan etika; dan

memelihara dan memupuk persatuan dan kesatuan bangsa.

Gary Flewelling dan William Higginson (2003)8 menggambarkan peran guru sebagai berikut:

1. Memberikan stimulasi kepada siswa dengan menyedian tugas-tugas pembelajaran yang kaya (rich learning tasks) dan terancang dengan baik untuk meningkatkan perkembangan intelektual, emosional, spiritual, dan sosial;

2. Berinteraksi dengan siswa untuk mendorong keberanian, mengilhami, menantang, berdiskusi, berbagi, menjelaskan, menegaskan, merefleksi, menilai dan merayakan perkembangan, pertumbuhan dan keberhasilan;

3. Menunjukkan manfaat yang diperoleh dari mempelajari suatu pokok bahasan;

4. Berperan sebagai seseorang yang membantu, seseorang yang mengerahkan dan memberi penegasan, seseorang yang memberi jiwa dan mengilhami siswa dengan cara membangkitkan rasa ingin tahu, rasa antusias, gairah dari seorang pembelajar yang berani mengambil resiko (risk taking learning), dengan demikian guru berperan sebagai pemberi informasi (informer), fasilitator, dan seorang artis.

Menurut Dr. Ahmad Tafsir

Guru (pendidik) ialah siapa saja yang bertanggung jawab terhadap perkembangan anak didik baik dari segi potensi kognitif, afektif, maupun potensi psikomotorik. Tugas guru dalam pandangan islam ialah mendidik. Mendidik merupakan tugas yang amat luas. Sebagian dilakukan dengan cara mengajar, sebagian ada yang dilakukan dengan memberikan dorongan, memberi contoh (suri tauladan), menghukum, dan lain-lain.

Menurut E. Mulyasa “2003:53” 
Pendidik harus memiliki kualifikasi akademik dan kompetensi sebagai agen pembelajaran sehat jasmani dan rohani serta memiliki kemampuan untuk mewujudkan tujuan pendidikan nasional.(E. Mulyasa, 2003:53)

\section{GURU INDONESIA DAN TANTANGAN PROFESIONALISME}

Guru sebagai model/pedoman adalah guru sebagai contoh atau teladan bagi anak khususnya dan masyarakat pada umumnya. Dan guru memiliki tugas untuk mencerdaskan seorang murid Tentu saja karena model haruslah yang baik, segala tingkah lakunya tidak bertentangan dengan norma dan nilai yang berlaku dimasyarakat. Segala bentuk penyimpangan tidak akan terjadi jika guru, orang tua dan masyarakat mampu memberikan teladan yang baik bagi anak, potensi untuk berbuat yang melanggar norma, aturan itu akan semakin minim.

Kompetensi profesional merupakan kemampuan dasar yang harus dimiliki oleh guru. Ada beberapa cadangan ahli tentang kompetensi profesional guru. Menurut cooper (1985:15) terbagi menjadi 4 komponen kompetensi dasar, yakni:

Mempunyai pengetahuan tentang belajar dan tingkah laku manusia.

Mempunyai pengetahuan dan mengusai bidang studi yang dibinanya.

Mempunyai sikap yang tepat tentang diri sendiri, sekolah, teman sejawat dan bidang studi yang dibinanya.

Mempunyai keterampilan dalam teknik mengajar.

\section{SIMPULAN}

profesi secara etimologi berasal dari kata profession yang berasal dari bahasa latin profesus yang berarti "mampu atau ahli dalam suatu bentuk pekerjaan ". Profesi adalah suatu pekerjaan atau jabatan yang menuntut keahlian tertentu. artinya suatu pekerjaan atau jabatan yang di sebut profesi tidak dapat dipegang oleh sembarangan orang, tetapi memerlukan persiapan melalui pendidikan dan pelatihan secara khusus . Walaupun pada kenyataannya masih terdapat guru yang tidak memiliki latar belakang pendidikan bidang keguruan. Guru dapat melakukan melaksanakan evaluasi yang efektif serta menggunakan hasilnya untuk mengetahui peserta dan kemajuan siswa serta dapat melakukan perbaikan dan pengembangan.

Guru sebagai model/pedoman adalah guru sebagai contoh atau teladan bagi anak khususnya dan masyarakat pada umumnya. Dan guru memiliki tugas untuk mencerdaskan seorang murid Tentu saja karena model haruslah yang baik, segala tingkah lakunya tidak bertentangan dengan norma dan nilai yang berlaku dimasyarakat. Kompetensi profesional merupakan kemampuan dasar yang harus dimiliki oleh guru. Ada beberapa cadangan ahli 
tentang kompetensi profesional guru. Mempunyai pengetahuan tentang belajar dan tingkah lakumanusia.Mempunyai pengetahuan dan mengusai bidang studi yang dibinanya.

\section{REFERENSI}

Efendi, I., Prawitasari, M., \& Susanto, H. (2021). Implementasi Penilaian Pembelajaran Pada Kurikulum 2013 Mata Pelajaran Sejarah. Prabayaksa: Journal of History Education, 1(1), 21-25.

Susanto, H. (2020). Profesi Keguruan. Banjarmasin: FKIP Universitas Lambung Mangkurat.

Susanto, H., \& Akmal, H. (2018). Efektivitas Penggunaan Aplikasi Pembelajaran Berbasis Mobile Smartphone Sebagai Media Pengenalan Sejarah Lokal Masa Revolusi Fisik Di Kalimantan Selatan Pada Siswa Sekolah Menengah Atas. HISTORIA: Jurnal Program Studi Pendidikan Sejarah, 6(2), 197-206.

Susanto, H., Irmawati, I., Akmal, H., \& Abbas, E. W. (2021). Media Film Dokumenter Masuknya Islam Ke Nusantara dan Pengaruhnya Terhadap Keterampilan Berpikir Kritis Siswa. HISTORIA: Jurnal Program Studi Pendidikan Sejarah, 9(1).

Syaharuddin, S., \& Susanto, H. (2019). Sejarah Pendidikan Indonesia (Era Pra Kolonialisme Nusantara sampai Reformasi). Banjarmasin: FKIP Universitas Lambung Mangkurat.

SiswaDewi Mutmainah1, Kamaluddin2, Peran Guru Pendidikan Pancasila dan Kewarganegaraan Dalam Membentuk Sikap dan Kepribadian

Askhabul Kirom, PERAN GURU DAN PESERTA DIDIK DALAM PROSES PEMBELAJARAN BERBASIS MULTIKULTURAL 